\title{
8. READING JAPANESE REFLECTIONS OF AUSTRALIA
}

\author{
Masayo Tada
} What interests me in reading Japanese accounts of them. When Japanese authors express their impressions of Australia, these impressions are inevitably based on their comparisons of Australia and Japan. In other words, these authors' reflections of Australia, in fact, also reflect what they identified as Japaneseness.

Considering comparative perspectives in these accounts, I would like to suggest that Japanese accounts of Australia can be important sources for an understanding of Japanese and Australian societies and for the examination of various transnational issues. I will elaborate on this by introducing some Japanese authors' reflections of gender issues in Australia.

Firstly, these accounts can be interesting material to study about Japan. To my mind, it is far more important to consider why Japanese people hold or express certain impressions of Australia, than trying to judge the accuracy of their portrait of Australia. Japanese reflections of Australia can be investigated through an examination of a writer's gender, age, socio-economic status and historical circumstances associated with the production of the material. Such 
investigation will also involve the examination of Japanese assumptions about Japaneseness. Thus Japanese accounts of Australia can be a point of departure for further studies of Japanese society.

Let me give you some examples of Japanese reflections of gender issues in Australia since the 1970s. The authors of writings on Australian society published in the 1970s were mainly government officials, business people and journalists who had opportunities to work in Australia for a period of time. They tended to be the well-educated male élite of Japanese society, and some of them represented Australian husbands as family men who contributed much to housework. Oikawa Kineo was a 35-year-old exchange NHK (Nihon Hōsō Kyōkai: Japan Broadcasting Corporation) broadcaster with the ABC in Melbourne between 1971 and $1973 .{ }^{1}$ In his accounts of social life and people in Melbourne, he represents Australian husbands as being domesticated and dominated by their wives, and expresses surprise and sympathy for them. ${ }^{2}$ This is common in some Japanese male writings on Australia in the 1970s, and remains potent in Japanese images of the 'Australian husband' to the extent that the term has these specific connotations. ${ }^{3}$

Gender relations in Australia were thus represented as otherness to what they identified as Japanese gender relations, and this representation was also evident in the next decades. Beginning in the 1980s more female authors produced accounts of Australia. These authors were often those with children who came to Australia due to their husband's work, and their writings focus on issues such as education and women's status in Australia in comparison with Japan. ${ }^{4}$ Because of an increasing number of male expatriate employees of Japanese institutions living overseas with their wives and children, the issues concerning overseas life and returnee children became more salient social issues in Japan. ${ }^{5}$ Ogata Masako lived in Sydney for five years with her three-year-old daughter, accompanying her husband who worked there, and wrote about her life in Sydney with a focus on raising her child. Ogata remarks on education free of pressure and husbands and wives relating as equal 
partners in her book published in 1982. Satō Machiko, who has lived in Australia since 1973 with her husband and children, produced three books on Australia in the 1980s. ${ }^{6}$ She depicts education and the social conditions of women in Australia favourably in comparison with Japan. Sato discusses an education in Australia that focuses on cultivating students' individuality and creativity, the relatively equal gender relations, and independent youth, and criticises Japanese education that focuses on rote-learning and controlling students, women's subservient status, and youths' dependence on their parents. ${ }^{\text {? }}$

In the 1990s, with an increase in the number of Japanese visiting or living in Australia, authors of accounts of Australia were more diverse, including travellers, housewives, exchange students, Japanese language teachers and migrants. Many such essays focus not only on their cross-cultural experience, but their search for self. It was popular for Japanese women to study and travel abroad to the extent that Japanese women who lived in foreign countries outnumbered Japanese men in 1999. ${ }^{8}$ Female accounts of the social conditions of women in Australia continued to be produced through the 1990s, and they tended to represent Australia as a care-free country. ${ }^{9}$ These authors lived and travelled in the country for a relatively long period when they were in their twenties. Mothers who travelled and lived in Australia with their children represented Australia as a place where they could rediscover their own self without the social pressure and restrictions they felt in Japan. ${ }^{10}$ Okumura Noriko, a single mother who travelled and lived in Australia with her daughter, represented Australia as a place where she could be herself because in Australia there were very few social restrictions on women and mothers. She feels that a single mother tends to be treated as an aberration in Japan. ${ }^{11}$

To understand continuing interests in gender issues in Australia expressed in Japanese accounts of Australia between the 1970s and the 1990s, it is useful to look at some statistical data. In Japan, a survey on time use and leisure has been conducted every five years since 1976. In 1976, 30- to 39-yearold husbands with children spent nine minutes on housework 
and childcare and five minutes shopping per day. A similar survey has been carried out in Australia every five years since 1992. Making a comparison of Japan and Australia, time spent per day on housework and related work (childcare, nursing and shopping) was, in Japan, 24 minutes by men and 332 minutes by women in 1991, and, in Australia, 150 minutes by men and 291 minutes by women in $1992 .^{12}$ Although we should consider a variety of other issues in investigating Japanese reflections of gender issues in Australia, including Japanese assumptions about Japan, the continuing gender gap in time spent on housework in Japan provides part of the explanation of the ways in which some Japanese authors wrote about gender issues in Australia.

In looking at these comparative data, while some Australian women may not agree, for instance, with Japanese representations of the Australian husband, it is quite understandable that some Japanese people viewed the Australian husband as being a great contributor to housework. It would also be interesting to compare situations of single mothers in Australia and Japan to understand why some Japanese single mothers somehow felt more comfortable in Australia.

This leads to my second point, that Japanese accounts of Australia can also be important sources for understanding Australia through cross-cultural comparative analyses. Although I talked only about gender issues here, these accounts are rich sources of other interesting topics for cross-cultural comparison.

This relates to my third point. These topics can also be seen as transnational topics, which aren't topics relevant only to Australia and Japan. By looking at societies comparatively, we are able to deepen our understanding. However, I strongly feel that there is a need to overcome the kinds of comparisons based on stereotypical assumptions about certain countries or regions, such as the conventional opposition between the West and the East. A kind of comparative perspective that makes us reconsider our own assumptions about national or regional 
characteristics is very important. For example, Japanese portraits of Australia provide a chance for reflecting on assumptions about Australia and Japan, and seeing the two countries with fresh eyes.

To conclude, Japanese accounts of Australia selected for English translation in this project can be useful for encouraging people to study further about many interesting transnational issues in the contexts of Australia and Japan. If these accounts were read simply as generalised Japanese-typical images of Australia, this would be rather a retreat from a better understanding of Australian and Japanese societies as part of an increasingly transnational world. 


\section{Footnotes}

1 Japanese names are given in the East Asian order — family name followed by given or personal name.

2 Oikawa Kineo. 1975. Meruborun nōto. Tokyo: Nihon Hōsō Shuppankai.

For example, in a book on Australia published in 1990, two contributors refer to the Japanese myth of the 'Australian husband'. Nakano Fujio (ed.). 1990. Motto shiritai Osutoraria. pp.117, 135. Tokyo: Kōbundō.

Amaya Kimiko. 1986. Tondetta būmeran: Amaya-ke no kaigai kikoku shijo kyöiku funsenki. Tokyo: Kumon Shuppan. Endō Masako. 1983. Shidonî no gogo: My Days in Australia. Tokyo: Sanshūsha. Nakajima Yōko. 1984. Sunde mita Osutoraria: rika kyōshi no kansatsu nōto. Tokyo: Saimaru Shuppankai. Ogata Masako. 1982. Shidonî no nonbiri kosodate: Osutoraria no aozora no shita de. Tokyo: Chūo Kōronsha. Haruko Robinson. 1983. Mai Osutoraria: zaigo 18-nen no jānarisuto ga kataru sugao no rakkī kantorī. Tokyo: Jakku Bokkusu.

The number of Japanese nationals living abroad for more than three months and permanent expatriates, including those with dual nationality, had increased from 445,372 in 1980 to 620,174 in 1990. Japanese Statistics Bureau. 2001. Japan Statistical Yearbook. p.54. As for the number of Japanese children at the compulsory education age living abroad, it had dramatically increased from 27,465 in 1980 to 49,336 in 1990. Japanese Ministry of Education, Culture, Sports, Science and Technology. Education for Japanese Children living overseas and returnee children. 27 September, 2001 (cited 3 February, 2003), available at http://www.mext.go.jp/english/org/exchange/ 10e.htm

Satō Machiko. 1985. Ōsutoraria kara no tegami: sunde wakatta koseiha kyoiku to nobinobi kurashi. Tokyo: Gakuyō Shoin. Satō Machiko. 1987. Onnatachi no Ōsutoraria. Tokyo: Keisō Shobō. Satō Machiko. 1989. Gōorei no nai gakkō: Ōsutoraria no kyôiku kankaku. Tokyo: Gakuyō Shobō.

$7 \quad$ Satō Machiko. 1985. Ōsutoraria kara no tegami. It should be noted that in the 1980s Japanese people increasingly discussed in the educational reform debates the need to shift school education from cramming and competition to creativity and a more relaxed approach.

8 The Asahi Shimbun reported that Japanese women who lived in foreign countries had outnumbered Japanese men in 1999 for the first time since the commencement of the survey in $1976(402,575$ 
women and 393,277 men). Kaigai ni sumu nihonjin josei, dansei nuku: ryūgaku, NGO katsudō ikigai sagashi. p.2. Asahi Shimbun, 8 May, 2000. It is observed in the article that the major factor of the reversal was an increase in the number of women who pursued a meaningful life overseas by engaging in study or volunteer and $\mathrm{NGO}$ activities. The rate of increase of the number of Japanese women going to the Oceania region was 15.3 per cent compared with that in the previous year, which was the largest increase rate. In an ethnographic account of Japanese settlers in Australia, Satō Machiko describes recent Japanese settlers in Australia as 'lifestyle migrants' (seishin imin, literally 'spiritual migrants'), who desire to improve their quality of life in various ways, including by having a more easygoing, carefree life abroad. Satō Machiko. 1993. Shin kaigai teijū jidai: Ōsutoraria no Nihonjin. Tokyo: Shinchōsha. The English version of this book is Farewell to Nippon: Japanese Lifestyle Migrants in Australia, 2001, Melbourne: Trans Pacific Press.

Kitazawa Aiko. 1990. Harukanaru ao tea roa: Nyüjīrando, Ōsutoraria boshi taizaiki. Osaka: Shinbun Insatsu Shuppan Sentâ. Naruse Mayumi. 1997. Itsudatte jibun sagashi: Ōsutoraria kozure rȳ̄gaku ki. Tokyo: WAVE Shuppan.

Okumura Noriko. 1993. Fûten mama no Ōsutoraria. Tokyo: Gakuyō Shobō. Saitō Kiyoko. 1992. Shidonî karāchi shîn (Sydney's Cultural Scene). Sydney: Shakai Shisōsha.

12 Japanese Statistics Bureau. 1978. Japan Statistical Yearbook. pp.598-99. 1993-94. Japan Statistical Yearbook. pp.728-29. Australian Bureau of Statistics. 1992. How Australians Use Their Time. p.8. 